Strategy for Process/Product Model Development for the Hanford Waste Vitrification Plant

W. L. Kuhn

March 1996

Prepared for the U.S. Department of Energy under Contract DE-AC06-76RLO 1830

Pacific Northwest National Laboratory Operated for the U.S. Department of Energy by Battelle Memorial Institute

\title{
\%
}


PNNL-11038

UC-810

Project Technical Information

\section{Strategy for Process/Product Model Development for the Hanford Waste Vitrification Plant}

W. L. Kuhn

March 1996

Prepared for

the U.S. Department of Energy

under Contract DE-AC06-76RLO 1830

Pacific Northwest National Laboratory

Richland, Washington 99352

Reprint of historical document PHTD-C93-05.01C. Rev. 0, dated January 1994. Data, formatting, and other comventions reflect standards at the original date of printing. Technical peer reviews and editorial reviews may not have been performed. 


\section{DISCLAISTER}

This report wes piepared as an account of work sponscred by an agency of the United States Covernment. Neither the Unied States Covernment nor any agency thereof, nor Eàitelle Memorial Instituie, nor any of their employees, makes any warranty, express or implied, or assumes any legal liability or responsibility for the accuracy, completeness, or, us efulness of any information, apparalus, product, or process disclosed, or represents that its use would not infringe privately owned rights. Refesence herein io any specinic commercial product, process, or service by trade name, traciemark, manuf́cturer, or oihenwise dües not necessarily constitute or imply its endorsement, recommenciation, or favoring by the United Siates Government or any agency thereoi, or Bañelle Memorial Instituie. The views and opinions of authors expressed herein do not necessarily state or retlect those of the United States Government or any agency thereof.

\section{PACIFIC NORTHWEST NATIONAL LAEORATORY operzied by \\ BATTELLE \\ for the \\ UNITED STATES DEPARTMENT OF ENERGY under Contract DE-ACO6-76RLO $183 C$}

Printed in the United States of America

Available to DOE and DOE contractors from the

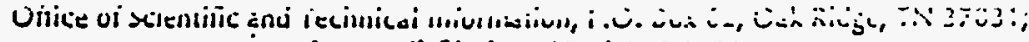
prices available from (615) 576-8401.

Available to the public from the National Technical Information Senvice, U.S. Department of Commerce, 5285 Port Royal Rd., Springield, VA 22161 


\section{Table of Contents}

1.0 Purpose $\ldots \ldots \ldots \ldots \ldots \ldots \ldots \ldots \ldots \ldots \ldots \ldots \ldots \ldots \ldots \ldots \ldots$

2.0 Project Needs Relevant to Process and Product Models $\ldots \ldots \ldots \ldots \ldots \ldots \ldots$. . . .

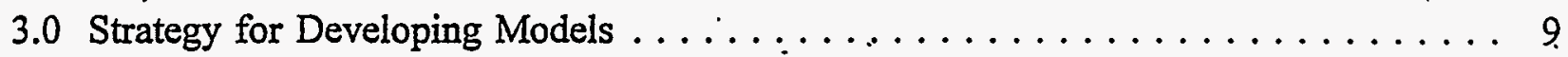

3.1 Glass Property Models..$\ldots \ldots \ldots \ldots \ldots \ldots \ldots \ldots$

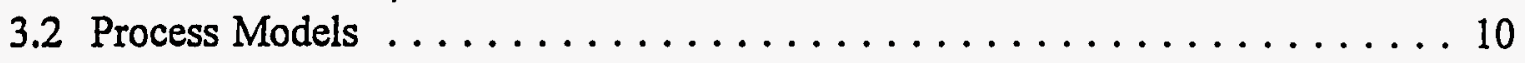

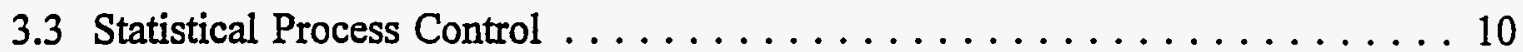

4.0 Strategy for Developing Requisite Models $\ldots \ldots \ldots \ldots \ldots \ldots \ldots \ldots \ldots \ldots$

4.1 Generating Models $\ldots \ldots \ldots \ldots \ldots \ldots \ldots \ldots \ldots \ldots \ldots \ldots \ldots \ldots$

4.2 Testing Statistical Process Control Algorithms $\ldots \ldots \ldots \ldots \ldots \ldots 13$

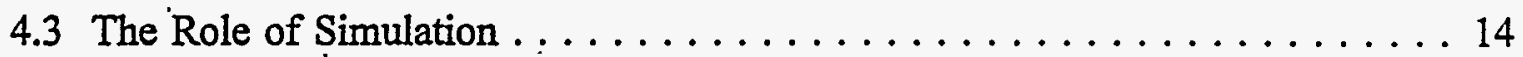

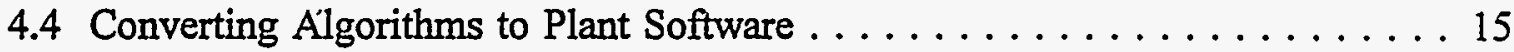

4.5 Relationship of Models to HWVP Project Elements $\ldots \ldots \ldots \ldots \ldots$

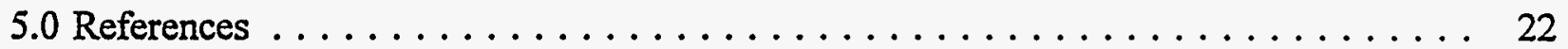

\section{Tables}

Table 1. Derivation of Process/Product Control Strategy From Project Needs . . . . . . . 1

Table 2. Relation of Process Models to HWVP Project Elements $\ldots \ldots \ldots \ldots \ldots 16$ 


\subsection{Purpose}

The purpose of this document is to describe the strategy being followed within the Pacific Northwest Laboratories/Hanford Waste Vitrification Plant Technology Development (PHTD) to provide Process and Product Models relevant to control of the vitrification process to ensure it produces an acceptable glass product. These models will be incorporated into a instrumentation system for product composition control and will affect many aspects of the operation of the Hanford Waste Vitrification Plant (HWVP). The strategy should be reviewed and commented on by the HWVP Operations, Engineering, and Waste Form Qualification functions:

\subsection{Project Needs Relevant to Process and Product Models}

A summary of project needs described below is presented in Table 1.

Table 1. Derivation of Process/Product Control Strategy From Project Needs $\left(^{* *}=\right.$ part of model development strategy)

\begin{tabular}{|c|c|c|c|}
\hline $\begin{array}{l}\text { Primary } \\
\text { Need }\end{array}$ & $\begin{array}{l}\text { Secondary } \\
\text { Need }\end{array}$ & $\begin{array}{l}\text { Tertiary } \\
\text { Need }\end{array}$ & Strategy \\
\hline \multirow{7}{*}{$\begin{array}{l}\text { Operate plant at } \\
\text { acceptable throughput }\end{array}$} & \multicolumn{2}{|c|}{ Glass with acceptable melting rate } & $\begin{array}{l}\text { Before operation, test } \\
\text { target glass for melting } \\
\text { rate }\end{array}$ \\
\hline & $\begin{array}{l}\text { Glass with acceptable } \\
\text { waste loading }\end{array}$ & $\begin{array}{l}\text { Target glass optimized } \\
\text { for waste loading while } \\
\text { meeting property } \\
\text { constraints }\end{array}$ & $\begin{array}{l}\text { **Use glass property } \\
\text { models to constrain } \\
\text { optimization of target } \\
\text { glass for waste loading }\end{array}$ \\
\hline & $\begin{array}{l}\text { Acceptable melter } \\
\text { lifetime }\end{array}$ & Acce & $\begin{array}{l}* * \text { Use statistical } \\
\text { methods and glass }\end{array}$ \\
\hline & \multirow{4}{*}{$\begin{array}{l}\text { Acceptable melter down } \\
\text { time }\end{array}$} & molten glass & $\begin{array}{l}\text { control composition of } \\
\text { SME slurry }\end{array}$ \\
\hline & & \multirow{3}{*}{$\begin{array}{l}\text { No significant } \\
\text { precipitation of insoluble } \\
\text { or crystallized phases in } \\
\text { melter }\end{array}$} & $\begin{array}{l}\text { Develop compliant } \\
\text { glass composition }\end{array}$ \\
\hline & & & $\begin{array}{l}\text { Include liquidus in } \\
\text { glass property models }\end{array}$ \\
\hline & & & Set specs on plant feed \\
\hline
\end{tabular}




\begin{tabular}{|c|c|c|c|c|c|}
\hline \multicolumn{3}{|c|}{$\begin{array}{c}\text { Primary } \\
\text { Need }\end{array}$} & $\begin{array}{c}\text { Secondary } \\
\text { Need }\end{array}$ & Tertiary & $\rightarrow \quad$ Strategy \\
\hline \multirow{3}{*}{\multicolumn{2}{|c|}{ - }} & & \multirow{3}{*}{$\begin{array}{l}\text { Minimal rejection of } \\
\text { SME batches }\end{array}$} & $\begin{array}{l}\text { Cushion between target } \\
\text { glass composition and } \\
\text { property constraints }\end{array}$ & $\begin{array}{l}* * \text { Use statistical } \\
\text { methods to select target } \\
\text { glass composition }\end{array}$ \\
\hline & & & & $\begin{array}{l}\text { Good estimates of } \\
\text { contents of SME }\end{array}$ & $\begin{array}{l}\text { **Use measurement } \\
\text { error modeling to } \\
\text { reconcile measurements } \\
\text { with known mass } \\
\text { balances }\end{array}$ \\
\hline & & & & & $\begin{array}{l}\text { **Use statistical } \\
\text { process control } \\
\text { methods to control } \\
\text { release of SME batches } \\
\text { per glass property } \\
\text { constraints }\end{array}$ \\
\hline \multirow{6}{*}{\multicolumn{3}{|c|}{$\begin{array}{c}\text { Meet WAPS } \\
\text { requirements } \\
\text { : }\end{array}$}} & \multirow[b]{2}{*}{$\begin{array}{l}\text { Acceptable glass } \\
\text { durability }\end{array}$} & Meet durability constraint & $\begin{array}{l}\text { Include durability in } \\
\text { glass property model }\end{array}$ \\
\hline & & & & & $\begin{array}{l}\text { **Use statistical } \\
\text { process control } \\
\text { methods to control } \\
\text { release of SME batches } \\
\text { per glass property } \\
\text { constraints }\end{array}$ \\
\hline & & & $\begin{array}{l}\text { Document glass chemical } \\
\text { and radiochemical } \\
\text { composition }\end{array}$ & $\begin{array}{l}\text { Good estimates of } \\
\text { contents of SME }\end{array}$ & $\begin{array}{l}* * \text { Use measurement } \\
\text { error modeling to } \\
\text { reconcile measurements } \\
\text { with known mass } \\
\text { balances }\end{array}$ \\
\hline & & & $\begin{array}{l}\text { Acceptable heat } \\
\text { generation rate in } \\
\text { canisters }\end{array}$ & $\begin{array}{l}\text { Acceptable radionuclide } \\
\text { inventory in glass }\end{array}$ & \multirow{3}{*}{$\begin{array}{l}\text { Limit waste loading as } \\
\text { necessary }\end{array}$} \\
\hline & & & $\begin{array}{l}\text { Acceptable radiation field } \\
\text { at canisters }\end{array}$ & $\begin{array}{l}\text { Acceptable radionuclide } \\
\text { inventory in glass }\end{array}$ & \\
\hline & & & $\begin{array}{l}\text { Acceptable criticality } \\
\text { factor for canisters }\end{array}$ & $\begin{array}{l}\text { Acceptable radionuclide } \\
\text { inventory in glass }\end{array}$ & \\
\hline \multicolumn{3}{|c|}{ Document operations } & $\begin{array}{l}\text { Document glass chemical } \\
\text { and radiochemical } \\
\text { composition }\end{array}$ & $\begin{array}{l}\text { Good estimates of } \\
\text { contents of SME }\end{array}$ & $\begin{array}{l}* * \text { Use measurement } \\
\text { error modeling to } \\
\text { reconcile measurements } \\
\text { with known mass } \\
\text { balances }\end{array}$ \\
\hline
\end{tabular}


To fulfill the mission of the HWVP, its operators must, within a prescribed time, convert High Level Waste (HLW) slurries into glass in canisters suitable for disposal in a federally licensed geologic repository. To do this; they must

- operate the plant at the intended processing rate

- $\quad$ produce glass with properties that meet Waste Acceptance Product Specifications (WAPS) (U.S. DOE, 1993)

- $\quad$ comply with reporting requirements.

Because the processing rate is limited by the capacity of the melter, the operator must maintain an adequate waste loading and attain the design melting rate during operation. To accomplish this, the operator must:

- $\quad$ reach the intended lifetime of the melter refractory,

- keep the melter free of excessive precipitated or undissolved solids,

- attain the intended electrical power dissipation in the molten glass,

- attain the intended rate of convective heat transfer to the glass/slurry interface in the melter, and

- provide to the melter a slurry that melts into the glass fast enough to sustain the necessary glass production rate.

The last of these objectives is met by optimizing the melting rate for a given melter size while meeting the other objectives, and then sizing the melter to provide an acceptable glass production rate. The first four objectives must be translated into objectives pertaining more directly to the glass in the melter, as follows.

- The viscosity of the molten glass must be kept low enough that acceptably intense mixing occurs by natural convection, but high enough to acceptably limit the corrosion rate of the refractory. 
- The liquidus temperatures of the molten glass must be kept low enough to limit precipitation of solids in the melter.

- The electrical conductivity of the molten glass must be kept low enough that the current is acceptably low, but large enough that the voltage is acceptably low.

The properties of interest are strong functions of both temperature and the composition of the glass. Essentially, the operating temperature of the melter must be high enough to melt the feed slurry rapidly, but low enough not to consume the refractory rapidly. Therefore, as a practical matter, the control objectives must be met.by controlling the composition of the glass. That is, the composition of glass in the melter must be controlled to meet simultaneously the following process control constraints.

- Viscosity must remain below an upper limit

- Viscosity must remain above a lower limit

- Electrical conductivity must remain below an upper limit

- Electrical conductivity must remain above a lower limit

- Liquidus temperature must remain below an upper limit, for pertinent solid phases

In addition, the glass in a canister must be suitable for disposal. Suitability has been defined in the WAPS to include specifications of maximum acceptable:

- Rate of dissolution of glass per a specified Product Consistency Test (PCT) (Jantzen, 1992a,b)

- Gamma emission rate at the surface of a canister

- Heat generation rate of a canister

The first of these suitability constraints is specified in terms of a statistical statement pertaining to a collection of canisters. This statement is evolving, but for the purposes of determining a process operation and control strategy, it is sufficient to know that the 
specification is not applied to each canister individually. The last two suitability constraints involve the inventory of certain radionuclides, primarily $\mathrm{Cs}^{137}$ and $\mathrm{Sr}^{90} / \mathrm{Y}^{90}$, in the canister (the radiation objective also involves secondarily the concentration of major species in the glass because of effects on shielding). These inventories, in turn, depend on the radionuclide concentration in the glass and the amount of glass in a canister. The latter is known from the weight of a filled canister. Furthermore, for a known radionuclide composition in the waste being vitrified, the radionuclide concentration in the glass depends only on the waste loading. Accordingly, the following suitability constraints, based on the WAPS, must be obeyed.

- PCT dissolution rate of glass in a canister must satisfy a statistically defined upper limit.

- Waste loading must remain below an upper limit.

The WAPS also require that the operator report a number of attributes of the glass actually produced, viz. the actual oxide composition of the glass, the radionuclide inventories, and selected properties (e.g. glass transition temperature and crystallinity).

The operator does not have direct control over the composition of the glass, although it can be measured. The composition must be controlled by controlling the volumes or masses of materials transferred to and from process tanks in the melter feed system.

The melter feed system includes the following major tanks: the Slurry Receipt and Adjustment Tank (SRAT), the Slurry Mix Evaporator (SME), the Process Frit Slurry Feed Tank (PFSFT), the Recycle Waste Collection Tank (RWCT), and the Melter Feed Tank (MFT). Waste enters the SRAT and is passed on to the SME. Any components volatilizing from the melter are scrubbed from the off-gas and recycled to the RWCT where they are combined with frit that has been used to decontaminate the surfaces of canisters. Fresh frit is added to the SME from the PFSFT in order to produce feed that, when vitrified, will produce a glass with acceptable properties. Part of the contents of the SME can be rejected to a to-bedetermined location upstream if needed to adjust the composition of the slurry in the SME. 
Once the contents of the SME are determined to be acceptable, they. are passed to the MFT. The contents of the MFT cannot be rejected or adjusted--they are passed unmodified to the melter--and the amount of material volatilized from the melter is very small relative to the material vitrified. Therefore, the composition of the glass in the melter on an oxide basis is essentially the composition on the same basis of the slurry in the SME, and the composition of the glass can be controlled by controlling the composition of the slurry in the SME.

Since virtually all mass released from the SME to the MFT continues on to and through the melter, the contents (composition and radionuclide inventories) of canisters actually produced can be inferred, using mass balances around the.SME-MFT-melter system, from measurements of the masses of components released from the SME. This allows product attributes to be computed from models and reported as required by the WAPS.

The composition of the slurry in the SME is determined by:

- the waste entering through the SRAT,

- the spent frit and recycled material entering through the RWCT,

- the fresh frit entering through the PFSFT,

- the proportions in which these three streams are mixed.

The contents of the RWCT are generally expected to be predominantly spent frit, such that the composition of the slurry in this tank is close to the composition of the fresh frit. Therefore, the composition of the slurry in the SME is essentially controlled by controlling:

- the composition of the fresh frit

- the ratio of the combined masses entering through the PFSFT and RWCT to the mass of waste entering through the SRAT.

In some cases it may be desirable to consume recycle material at a slower rate than it is generated. Normally, however, control of the composition of slurry in the SME occurs in two 
steps at two times. First, the composition of the frit is determined prior to processing a given waste type (e.g., Nuclear Cladding Acid Waste (NCAW)), based on the expected composition of the entering waste. Second, the amount of frit (spent plus fresh) added to the SME is determined for each batch during processing of a given waste type.

The target glass composition ideally needs to be optimized (for each batch) to simultaneously:

- $\quad$ maximize the waste loading

- maximize the melting rate

- minimize the rate of rejection of SME batches after uncertainties in measurements and in the property models are taken into account

Some weighting of these multiple objectives must be decided by the project in order to establish a target glass composition because mathematically one can not simultaneously. exactly satisfy multiple objective functions. Target glass compositions can be determined for .whole waste types as well as individual batches.

The frequency of rejection of SME batches depends on the target glass composition, since at the time frit is added to the SME there is only one degree of freedom--the ratio of frit to current SME contents--and this does not allow glass of arbitrary composition to be made. If the properties of the target glass composition are too close to the property constraints, it may not be possible, given uncertainties in the estimated current composition of the SME and in the property models, to find a ratio of frit to SME contents that results in acceptable glass properties when acceptability.is evaluated at a typical confidence level (e.g., 95\%).

The glass composition is determined by the composition of the frit and waste and the waste loading. Since the waste loading is optimized under the glass property constraints, then, for a given assumed waste composition, the frit composition effectively determines the glass composition. Therefore, prior to vitrifying a given waste stream, the frit composition must be selected to provide 
- $\quad$ an adequate waste loading

- $\quad$ an adequate melting rate

- a minimal frequency of rejection of SME batches.

Once the frit composition is selected and processing begins for a given waste type, the operator must keep the plant operating and satisfy the WAPS. This requires the following.

- The composition of the feed slurry must be measured before the behavior of the process can be either reported or controlled. Specifically, measurements must be taken that allow a determination of the masses of components in slurries in tanks that can be related to the masses of oxides in glass that would result from vitrifying the slurry.

These measurements are:

-- volume of slurry in a tank,

-- density of slurry in a tank,

-- composition (mass fraction) of components in the slurry. This requires that the slurry be sampled it's sample mass (weight) be determined, and the sample composition be determined.

The uncertainty in the composition is described in terms of a covariance matrix over the various components. Uncertainty in volume and density will initially be described in terms of variance vectors.

- Glass characteristics such as oxide composition, radionuclide concentrations, and attributes derived from these, i.e. the heat loading and radiation fields for a canister, must be reported to comply with the WAPS.

Physical properties of glass in the melter, the durability of glass in canisters, and the occurrence of insoluble or precipitated phases in molten glass must be controlled in order to fulfill the HWVP mission by sustaining operation of the melter and by filling 
canisters with glass. We embrace the philosophy, developed at the Savannah River Site for the Defense Waste Processing Facility (DWPF), of indirectly controlling these properties by controlling the feed slurry composition at the (SME).

\subsection{Strategy for Developing Models}

\subsection{Glass Property Models}

Since only the composition of the feed to the melter can be directly measured and controlled by the operator, a set of glass property models that relate process control constraints to the composition of the feed are needed as a basis for reporting and controlling the glass product. These property models must:

- Predict properties of glass in the melter or in a canister in terms of the oxide composition. This is discussed further in Hrma and Piepel, 1992.

- Predict heat loading in terms of the radionuclide concentrations in the glass in a canister. Simple linear relationships exist that can be described in spreadsheet form, if desired.

- Predict the radiation field at the surface of a canister in terms of the radionuclide concentrations and with the oxide composition (which affect the internal shielding) of glass in a canister. Standard codes, such as ISOSHLD, exist that, for a given oxide composition of the glass and canister size and shape, can create simple linear relationships between radionuclide inventories and their contribution to the radiation field.

Given these product models and any corresponding expressions of uncertainty in model predictions, the acceptability of the glass relative to both continued operation of the plant and compliance with the WAPS can be determined any time the composition of the glass is 
estimated.

\subsection{Process Models}

To measure and control the composition of the glass, process models in the form of

algorittms (standard calculational procedures) are required to:

- Rectify measurements of composition to conform with mass balances for mixing operations; i.e., reconcile measurements with a priori understanding of the process.

- Add frit to the SME such that there is an acceptable probability that the oxide composition and radionuclide concentrations comply with a statistically defined standard.

- Accept or, reject feed in the SME for release to the melter feed tank.

- $\quad$ Correct the contents of the SME if they are not acceptable for release to the melter feed tank.

- Diagnose fluctuations in and intercomparisons between process measurements to determine if the process is under control.

.Each of the above must be done while accounting systematically for uncertainties in measurements, glass property models, and specifications.

\subsection{Statistical Process Control}

The feed preparation system of the HWVP is essentially a simple batch mixing process. It is expected that proper mixing will be provided in tanks such that the composition and density of the slurries they contain are uniform over the volume of the tank. Then, from the perspective of process control, the essential feature of the process is its statistical nature, 
which results from uncertainties in process measurements. Statistical process control concepts must be invoked to account for inevitable random errors in all measurements and to provide a rational basis for making discrete control decisions based on slightly erroneous measurements. Statistical Process Control Algorithms are needed to accomplish this, including the following. (See Bryan and Piepel, 1993a.)

- A Measurement Correction Algorithm used to reconcile measurements, using the "measurement eiror modeling" technique, with mass balance constraints. Optimal estimates of the true values of the measured variables are obtained by a least squares fit to the measured values, where the least squares fit is weighted by a priori estimates of the covariances of the measured values and constrained by mass balances that describe from first principles the mixing that occurs among or within tanks before each new set of measurements is taken.

- A SME Targeting Algorithm used to compute the amount of frit to add to the SME such that, per a statistically defined standard, an acceptable batch of melter feed slurry results.

- A Feed Test Algorithm (Bryan and Piepel, 1993b) used to determine, per a statistically defined standard, if the contents of the SME, would result in acceptable melt glass properties.

- A SME Remediation Algorithm used to determine material to be added to the SME to correct an unacceptable SME batch.

- A Product Consistency Algorithm which will use tolerance intervals and best estimates of product composition to predict whether the product material, for a given waste type, will satisfy specification 1.3 in the EM-WAPS.

- A Process Monitoring Algorithm used to monitor departures from the expected 
variability of the process, where normal variability is established by testing prior to radioactive operation. Process control charting is needed to

- Reveal when the variability of the process suggests a significant problem, such as systematic operator error or instrumentation failure.

- $\quad$ Prevent needless and worthless interruption of the process caused by over interpretation or misinterpretation of normal variations in process measurements.

\subsection{Strategy for Developing Requisite Models}

Implementing the strategy described above requires three basic steps: generation of process and product models; qualification testing of the models; conversion of the models to software useful to plant operators.

\subsection{Generating.Models}

Generation of process models: Since the essence of the process control problem is statistical, statistical process control algorithms must be adopted or generated by statisticians, scientists, and engineers to provide the Measurement Correction Algorithm, SME Targeting Algorithm, Feed Test Algorithm, and Process Monitoring Algorithm. This process is described in Bryan and Piepel, 1993a.

Generation of product models: The characteristics of models for heat generation rate and radiation field in terms of radionuclide inventories in a canister, and for criticality factor in terms of oxide composition and radionuclide inventory, are the same for DWPF as for HWVP because the relevant physical phenomena are the same. Minor changes may be needed due to different canister geometries and inclusion of different major oxides in the models, but the mathematical form of models developed and qualified for the DWPF should be suitable for 
use for the HWVP. Development activities should consist mainly of confirming the models for an HWVP glass and importing the models into the HWVP QA system.

\subsection{Testing Statistical Process Control Algorithms}

The HWVP, or any similar vitrification facility, is essentially a batch mixing operation. Its behavior should be readily predicted by mass balances describing perfect mixing in the main process tanks. The remaining significant challenge is to understand and account for several important sources of uncertainty, including

- Departures of the waste composition from that assumed in formulating the frit

- Random errors in process measurements, viz. the composition of slurries, the solids loading, and the liquid level in process tanks

- Random errors in transferring intended volumes of slurry from tank to tank

- Systematic errors, such as drift in process instrumentation

- Systematic departures from ideal behavior in the process, such as settling and resuspension of solids in tanks

Operators of the process must show that errors can be controlled to levels that ensure sustained operation of the plant, compliance with the WAPS, and compliance with reporting requirements. The ideal test of statistical process control algorithms would be to operate the actual plant and modify the algorithms as necessary to achieve satisfactory results. This is not practical because of the additional cost of operating the plant that would be incurred. Furthermore, the operation of the plant will be tightly controlled to minimize plant risks. Hence, the algorithms must be tested and qualified before they are used to operate the actual plant. Some prior mearis of testing is needed.

Testing through operation of a representative subset of the plant is not likely. Pilot-scale testing is planned, but would not include a functional equivalent in terms of statistical process control to the actual multiple tank HWVP feed system. In particular, testing is planned using 
a single tank to perform the functions of three tanks (SRAT, SME; MFT), such that transfers of slurry among the SRAT, SME, and MFT and with the PFSFT and RWCT will not be represented by operation of the pilot scale system ${ }^{l}$. Consequently, the Measurement Correction Algorithm, in particular, cannot be tested or qualified. Control and reporting methods can be qualified sufficiently to allow operation of the actual plant by simulating the performance of the plant using the same control methods that would be used to operate the actual plant.

\subsection{The Role of Simulation}

Simulating the operation of the feed system is needed for:

- Plant Startup Qualification The result of the simulation portrays the normal variability of the process and illustrates that the consequences are acceptable, allowing the control system to be qualified for startup of non-radioactive operations.

- Algorithm Testing Simulation provides a representation of the actual process which can interact realistically with statistical process control algorithms for the purpose of testing statistical process control algorithms. Through such simulations one can evaluate the sensitivity of the process to the precision, accuracy, and stability of process instrumentation and particularly of the chemical analytical laboratory used to determine slurry compositions.

- Flowsheet Evaluation Simulation precipitates thorough analyses of the process flowsheet, instrumentation, measurement errors, control logic, and the criteria for statistically- based process control decisions, and decreases the chance that either simple or obscure problems with the control logic will go unnoticed prior to plant startup. ${ }^{2}$.

\footnotetext{
'Versions of these algorithms can be constructed and used to help control pilot-scale testing, but successful control of the pilot-scale system would not ensure successful control of the multi-tank HWVP feed system.

${ }^{2}$ For example, a simple simulation can show that, if liquid level measurements are not precise, the "heel" left in process tanks can exceed flowsheet assumptions if transfers between tanks can be terminated by either the level in the emptying or the filling tank. The effect is obvious once revealed in a simulation, but might not be considered at all if not prompted by a simulation.
} 
A computer code is needed and is being developed that simulates operation of the plant to provide a software "test stand" for operation of the statistical process control algorithms (SPCAs). Accordingly, a Plant Simulation Code. (PSC) "test stand" is being constructed into which control algorithms, when implemented as computer subroutines, can be "plugged in" to estimate how the actual plant would respond.

The plant simulation includes mass balances that are the basis for plant design. It simulates measurement errors using a Monte Carlo approach. Any data reduction, such as averaging of multiple slurry samples and chemical analyses of samples, can be simulated the same way that it would be done in control and monitoring of the actual plants. In addition to responding to the SPCAs, the simulation incorporates the detailed strategy for controlling the process, including batch transfer sequences and criteria for starting and stopping transfers.

For a given sampling strategy (where taken, replication of sampling, replication of chemical analyses), batch sequencing strategy, and set of SPCAs, the simulated operation of the plant can be examined to predict the frequency of rejection of SME batches, variability of the glass composition, average throughput rate of the process, and other statistical measures of the acceptability of the real process.

\subsection{Converting Algorithms to Plant Software}

Eventually a software system for product composition control must be created and provided to operators of the HWVP. Process control algorithms developed and tested using the plant simulation code must then be converted into software compatible with the product composition control (PCC) system. The plant simulation code is not suited for use as a PCC system. Instead, a PCC system needs to be developed in concert with and by the same organization that develops the overall plant process control system. This could be the control system vendor, an engineering function within the HWVP project, or a third party contracted for this purpose.

\subsection{Relationship of Models to HWVP Project Elements}

The relationship of models to HWVP project elements is summarized in Table 2. 
Table 2. Relation of Process Models to HWVP Project Elements

\begin{tabular}{|c|c|c|c|c|c|}
\hline \multirow{2}{*}{$\begin{array}{l}\text { Results of Model } \\
\text { Development } \\
\text { Activity }\end{array}$} & \multirow[b]{2}{*}{ Deliverables } & \multicolumn{4}{|c|}{ Relationship to HWVP Project Elements } \\
\hline & & $\begin{array}{c}\text { Technology } \\
\text { Development }\end{array}$ & Design & Operations & $\begin{array}{l}\text { Waste Form } \\
\text { Qualification }\end{array}$ \\
\hline $\begin{array}{l}\text { Measurement } \\
\text { Correction Algorithm } \\
\text { (MCA) } \\
\text { [using measurement } \\
\text { error modeling } \\
\text { (MEM) teclniques] }\end{array}$ & $\begin{array}{l}\text { Equations and } \\
\text { documentation - } \\
\text { applicable to either } \\
\text { plant simulation code } \\
\text { or actual process } \\
\text { control system } \\
\text { Algorithm as computer } \\
\text { subroutine compatible } \\
\text { with Plant Simulation } \\
\text { Code }\end{array}$ & $\begin{array}{l}\text { Develop MCA for } \\
\text { HWVP flow diagram } \\
\text { and operating logic } \\
\text { Evaluate sampling and } \\
\text { analytical } \\
\text { instrumentation by } \\
\text { comparing } \\
\text { measurements to } \\
\text { expected mass } \\
\text { balances from } \\
\text { preparing test samples }\end{array}$ & $\begin{array}{l}\text { Improve control } \\
\text { strategy by combining } \\
\text { several measurements }\end{array}$ & $\begin{array}{l}\text { Rectify differences } \\
\text { between process } \\
\text { measurements and } \\
\text { mass balances, and } \\
\text { use rectified values as } \\
\text { basis for monitoring } \\
\text { and control }\end{array}$ & $\begin{array}{l}\text { Provide estimates of } \\
\text { composition for } \\
\text { production records }\end{array}$ \\
\hline $\begin{array}{l}\text { SME Targeting } \\
\text { Algorithm (STA) }\end{array}$ & $\begin{array}{l}\text { Equations and } \\
\text { documentation - } \\
\text { applicable to either } \\
\text { plant simulation code } \\
\text { or actual process } \\
\text { control system } \\
\text { Algorithm as computer } \\
\text { subroutine compatible } \\
\text { with Plant Simulation. } \\
\text { Code }\end{array}$ & $\begin{array}{l}\text { Develop SME } \\
\text { Targeting Algorithm } \\
\text { (STA) }\end{array}$ & & & $\begin{array}{l}\text { Select target } \\
\text { mixture for a single } \\
\text { SME batch }\end{array}$ \\
\hline
\end{tabular}


Table 2. Relation of Process Models to HWVP Project Elements (cont'd)

\begin{tabular}{|c|c|c|c|c|c|}
\hline \multirow{2}{*}{$\begin{array}{l}\text { Results of Model } \\
\text { Development } \\
\text { Activity }\end{array}$} & \multirow[b]{2}{*}{ Deliverables } & \multicolumn{4}{|c|}{ Relationship to HWVP Project Elements } \\
\hline & & $\begin{array}{c}\text { Technology } \\
\text { Development }\end{array}$ & Design & Operations & $\begin{array}{l}\text { Waste Form } \\
\text { Qualification }\end{array}$ \\
\hline $\begin{array}{l}\text { Glass Formulation } \\
\text { Algorithm (GFA) }\end{array}$ & $\begin{array}{l}\text { Equations and } \\
\text { documentation - } \\
\text { applicable to either } \\
\text { plant simulation code } \\
\text { or actual process } \\
\text { control system } \\
\end{array}$ & $\begin{array}{l}\text { Develop GFA } \\
\text { Algorithm using } \\
\text { optimization } \\
\text { techniques }\end{array}$ & Select frit composition & $\begin{array}{l}\text { Complete frit } \\
\text { composition to add to } \\
\text { SME for a whole } \\
\text { waste type }\end{array}$ & \\
\hline $\begin{array}{l}\text { Product Consistency } \\
\text { Algorithm (PCA) }\end{array}$ & $\begin{array}{l}\text { Equations and } \\
\text { documentation - } \\
\text { applicable to either } \\
\text { plant simulation code } \\
\text { or actual process } \\
\text { control. system } \\
\\
\text { Algorithm as computer } \\
\text { subroutine compatible } \\
\text { with Plant Simulation } \\
\text { Code } \\
\end{array}$ & Develop PCA & $\begin{array}{l}\text { Interact with GFA to } \\
\text { calculate frit } \\
\text { composition }\end{array}$ & $\begin{array}{l}\text { Input to frit } \\
\text { composition } \\
\text { calculation }\end{array}$ & $\begin{array}{l}\text { Provide basis for } \\
\text { complying with } \\
\text { WAPS } 1.3\end{array}$ \\
\hline $\begin{array}{l}\text { Feed Test Algorithm } \\
\text { (FTA) }\end{array}$ & $\begin{array}{l}\text { Equations and } \\
\text { documentation - } \\
\text { applicable to either } \\
\text { plant simulation code } \\
\text { or actual process } \\
\text { control system } \\
\\
\text { Algorithm as'computer } \\
\text { subroutine compatible } \\
\text { with Plant Simulation } \\
\text { Code }\end{array}$ & $\begin{array}{l}\text { Develop Feed Test } \\
\text { Algorithm }\end{array}$ & & $\begin{array}{l}\text { Test SME batch for } \\
\text { acceptability }\end{array}$ & $\begin{array}{l}\text { Provide } \\
\text { documentation of } \\
\text { compliance with } \\
\text { WAPS }\end{array}$ \\
\hline
\end{tabular}


Table 2. Relation of Process Models to HWVP Project Elements (cont'd)

\begin{tabular}{|c|c|c|c|c|c|}
\hline \multirow{2}{*}{$\begin{array}{c}\text { Results of Model } \\
\text { Development } \\
\text { Activity }\end{array}$} & \multirow[b]{2}{*}{ Deliverables } & \multicolumn{4}{|c|}{ Relationship to HWVP Project Elements } \\
\hline & & $\begin{array}{c}\text { Technology } \\
\text { Development }\end{array}$ & Design & Operations & $\begin{array}{l}\text { Waste Form } \\
\text { Qualification }\end{array}$ \\
\hline $\begin{array}{l}\text { SME Remediation } \\
\text { Algorithm (SRA) }\end{array}$ & $\begin{array}{l}\text { Equations and } \\
\text { documentation - } \\
\text { applicable to either } \\
\text { plant simulation code } \\
\text { or actual process } \\
\text { control system } \\
\text { Algorithm as computer } \\
\text { subroutine compatible } \\
\text { with Plant Simulation } \\
\text { Code }\end{array}$ & $\begin{array}{l}\text { Develop SME } \\
\text { Remediation } \\
\text { Algorithm (SRA) }\end{array}$ & v & $\begin{array}{l}\text { Compute material to } \\
\text { add to SME to make } \\
\text { contents acceptable for } \\
\text { release }\end{array}$ & \\
\hline $\begin{array}{l}\text { Plant Simulation } \\
\text { Code (PSC) }\end{array}$ & $\begin{array}{l}\text { FORTRAN code } \\
\text { configured to link to } \\
\text { and utilize process } \\
\text { control.algorithm } \\
\text { subroutines } \\
\text { Report(s) describing } \\
\text { simulated performance } \\
\text { of process control } \\
\text { algorithms for choices } \\
\text { of sampling strategy } \\
\text { and batch control logic }\end{array}$ & $\begin{array}{l}\text { Verify MCA, STA, } \\
\text { FTA } \\
\text { Simulate validation of } \\
\text { MCA, STA, FTA }\end{array}$ & $\begin{array}{l}\text { Evaluate consequences } \\
\text { of variability and } \\
\text { uncertainty of HWVP } \\
\text { feed } \\
\text { Confirm ability of } \\
\text { instrumentation to } \\
\text { meet WAPS } \\
\text { Confirm ability to } \\
\text { attain expected } \\
\text { process throughput }\end{array}$ & & $\begin{array}{l}\text { Demonstrate } \\
\text { stochastic nature of } \\
\text { process, for WFQ } \\
\text { Report } \\
\text { Demonstrate ability } \\
\text { of process control } \\
\text { algorithms to } \\
\text { comply with } \\
\text { WAPS, for WFQ } \\
\text { Report }\end{array}$ \\
\hline
\end{tabular}


Table 2. Relation of Process Models to HWVP Project Elements (cont'd)

\begin{tabular}{|c|c|c|c|c|c|}
\hline \multirow{2}{*}{$\begin{array}{l}\text { Results of Model } \\
\text { Development } \\
\text { Activity }\end{array}$} & \multirow[b]{2}{*}{ Deliverables } & \multicolumn{4}{|c|}{ Relationship to HWVP Project Elements } \\
\hline & & $\begin{array}{c}\text { Technology } \\
\text { Development }\end{array}$ & Design & Operations & $\begin{array}{l}\text { Waste Form } \\
\text { Qualification }\end{array}$ \\
\hline $\begin{array}{l}\text { Process Monitoring } \\
\text { Algorithm }\end{array}$ & $\begin{array}{l}\text { Equations and } \\
\text { documentation - } \\
\text { applicable to either } \\
\text { plant simulation code } \\
\text { or actual process } \\
\text { control system } \\
\text { Algorithm as computer } \\
\text { subroutine compatible } \\
\text { with Plant Simulation } \\
\text { Code }\end{array}$ & $\begin{array}{l}\text { Evaluate equipment } \\
\text { and instrumentation by } \\
\text { discerning departures } \\
\text { from normal process } \\
\text { fluctuations }\end{array}$ & & $\begin{array}{l}\text { Discern and interpret } \\
\text { departures from } \\
\text { acceptable process } \\
\text { control }\end{array}$ & $\cdot \cdot$ \\
\hline $\begin{array}{c}\text { Software } \\
\text { Implementing } \\
\text { Product Composition } \\
\text { Control in the } \\
\text { HWVP }\end{array}$ & $\begin{array}{l}\text { Consolidated software } \\
\text { implementation of all } \\
\text { process control } \\
\text { algorithms with } \\
\text { interface written for } \\
\text { actual operation and } \\
\text { not for the Plant } \\
\text { Simulation Code }\end{array}$ & $\begin{array}{l}\text { Assist instrumentation } \\
\text { subcontractor in } \\
\text { implementing MCA, } \\
\text { STA, and FTA for } \\
\text { operators of cold runs }\end{array}$ & $\begin{array}{l}\text { Use GFA to establish } \\
\text { reference frit } \\
\text { composition for } \\
\text { reference waste types }\end{array}$ & $\begin{array}{l}\text { Use MCA, STA, } \\
\text { FTA, to statistically } \\
\text { control the actual } \\
\text { plant }\end{array}$ & $\begin{array}{l}\text { Use FTA to } \\
\text { statistically track } \\
\text { acceptable canisters }\end{array}$ \\
\hline $\begin{array}{c}\text { Equations for Heat } \\
\text { Generation in a } \\
\text { Canister }\end{array}$ & $\begin{array}{l}\text { Equations and } \\
\text { documentation } \\
\text { Stand alone software, } \\
\text { e.g. on PC or work } \\
\text { station }\end{array}$ & $\begin{array}{l}\text { Verify applicability of } \\
\text { DWPF models to } \\
\text { HWVP }\end{array}$ & & · & $\begin{array}{l}\text { Calculate heat } \\
\text { generation rate } \\
\text { based on estimate of } \\
\text { radionuclide content } \\
\text { of a canister }\end{array}$ \\
\hline
\end{tabular}


Table 2. Relation of Process Models to HWVP Project Elements (cont'd)

\begin{tabular}{|c|c|c|c|c|c|}
\hline \multirow{2}{*}{$\begin{array}{c}\text { Results of Model } \\
\text { Development } \\
\text { Activity }\end{array}$} & \multirow[b]{2}{*}{ Deliverables } & \multicolumn{4}{|c|}{ Relationship to HWVP Project Elements } \\
\hline & & $\begin{array}{c}\text { Technology } \\
\text { Development }\end{array}$ & Design & Operations & $\begin{array}{l}\text { Waste Form } \\
\text { Qualification }\end{array}$ \\
\hline $\begin{array}{l}\text { Equations for } \\
\text { Radiation Field } \\
\text { Surrounding a } \\
\text { Canister }\end{array}$ & $\begin{array}{l}\text { Equations and } \\
\text { documentation } \\
\text { Stand alone software, } \\
\text { e.g. on PC or work } \\
\text { station }\end{array}$ & $\begin{array}{l}\text { Verify applicability of } \\
\text { DWPF models to } \\
\text { HWVP }\end{array}$ & & & $\begin{array}{l}\text { Calculate gamma } \\
\text { radiation field } \\
\text { surrounding a } \\
\text { canister based on } \\
\text { estimate of chemical } \\
\text { and radiochemical } \\
\text { content of canister }\end{array}$ \\
\hline $\begin{array}{l}\text { Confirmation of } \\
\text { Criticality Safety } \\
\text { Margin }\end{array}$ & $\begin{array}{l}\text { Equations and } \\
\text { documentation } \\
\text { Stand alone software, } \\
\text { e.g. on PC or work } \\
\text { station }\end{array}$ & $\begin{array}{l}\text { Verify applicability of } \\
\text { DWPF models to } \\
\text { HWVP }\end{array}$ & & & $\begin{array}{l}\text { Confirm safety } \\
\text { margin for } \\
\text { criticality }\end{array}$ \\
\hline
\end{tabular}




\subsection{REFERENCES}

Bryan, M.F. and G.F. Piepel. 1993a. Strategy for Product Composition Control in the Hanford Waste Vitrification Plant, PHTD-C93-05.01F, Pacific Northwest Laboratory, Richland, Washington.

Bryan, M.F. and G.F. Piepel. 1993b. Preliminary Feed Test Algorithm for the Hanford Waste Vitrification Product Composition Control System, PHTD-C93-05.01A, Pacific Northwest Laboratory, Richland, Washington. To be issued.

Hrma, P.R. and G.F. Piepel. 1992. Property/Composition Relationships for Hanford Waste Vitrification Plant Glasses--Preliminary Results Through CVS-II Phase 2, PHTD-9203.01/K897, Pacific Northwest Laboratory, Richland, Washington.

U.S. Department of Energy. 1993. Waste Acceptance Product Specifications for Vitrifies High-Level Waste Forms, EM-WAPS, Rev.0, February 1993, Office of Environmental Restoration and Waste Management, U.S. Department of Energy, Germantown, Maryland.

Jantzen, C.M. 1992a. Characterization of the Defense Waste processing Facility (DWPF) Environmental Assessment (EA) Glass Standard Reference Material, September 1992, WSRC-TR-92-346, Westinghouse Savannah River Company, Aiken, SC.

Jantzen, C.M. 1992b. Nuclear Waste Product Consistency Test Method Version 5.0, January 1992, WSRC-TR-90-539, Westinghouse Savannah River Company, Aiken, SC. 